Britain and Ireland) Co., Ltd. ; Rolls-Royce, Ltd. ; The Shell Petroleum Co., Ltd.; Tube Investments, Ltd. ; Vickers, Ltd.; The Wellcome Foundation, Ltd. These companies have accordingly established an Industrial Trust, to be known as the Industrial Fund for the Advancement of Scientific Education in Schools. For capital works at maintained schools, public funds are available, but no such help exists for independent schools and direct grant schools, at many of which the facilities are seriously inadequate through lack of capital resources, and it is therefore to these that the sponsoring companies are directing their intentions. The assistance will be given solely by the provision of capital grants towards the building, expansion, modernizing and equipping of science buildings in independent schools and direct grant schools in the United Kingdom, the Channel Islands and the Isle of Man. More than one and a half million pounds has already been guaranteed; but it is believed that many other companies that depend on adequate supplies of pure and applied scientists and technologists will wish to add their support. Indeed, only shortage of time has prevented their being approached already.

An Executive Committee of the Fund has been formed, consisting of the following : Sir Wilfrid Anson; Mr. R. A. Banks; Sir Hugh Beaver (chairman) ; Mr. E. H. O. Elkington ; Dr. Willis Jackson ; Mr. W. E. Jenkins; Prof. G. F. Mucklow ; Mr. J. A. Oriel ; Dr. F. Roffey ; Dr. C. P. Snow ; Sir Alexander Todd; Lieut.-Gen. Sir Ronald Weeks; Mr. A. H. Wilson. The secretary of the Committee is Mr. Peter Ashton, of Courtaulds, Ltd., and the address of the Fund is 20 Savile Row, London, W.I. It will be the responsibility of this Committee to adjudge and assess all applications; its decisions will take into account both the volume and quality of the existing science teaching in any school, as well as the nature of the proposals put forward to extend and improve it, and the steps which the school has taken to help itself.

\section{Future Policy of the Wellcome Trust}

Sir Henry Dale, chrirman of the Welleome Trust, has recently explained the activities of the Trust in relation to the Wellcome Foundation from which its funds are derived, and also the character of its benefactions up to date. The Trust came into existence in 1936 on the death of Sir Henry Wellcome, though the activities of the Foundation and its associated branches commenced much earlier. The first demand on the Trust was the payment of very heavy estate duty, for which Sir Henry Wellcome had made no provision in his will, and for the first five years of its existence all the income of the Trust, which was derived from dividends received on its shares in the Wellcome Foundation, Ltd., was devoted to paying off this duty. Although the Foundation's profits during the Second World War rose considerably, due to the expansion of business in the manufacture of medical and therapeutic supplies, most of the money was either taken as excess profits tax or used in the new capital expenditure demanded by the urgent war-time expansion of its activities. Nevertheless, the Trust has been able to function to a limited extent, the most notable of its benefactions being the endowment of a Wellcome chair of tropical medicine and a Wellcome chair of pharmacology in the University of London. In addition, it has given funds for numerous fellowships and studentships both in Britain and overseas, and has also made provision for an important new medical library for the Royal Society of Medicine, and for three large museum floors, for anatomy and pathology, as a major part of the new building of the Royal College of Surgeons in Lincoln's Inn Fields. Sir Henry Dale pointed out that whereas the activities of the Trust in the past have necessarily tended to be sporadic, the time has now been reached when it can be assured of a substential income and therefore has the opportunity to initiate a planned policy for spending its resources. To ensure such a longer-term policy and a more co-ordinated planning by the trustees, a full-time administrative staff is needed to deal with the charitable aspect of the Trust's functions, and Dr. F. H. K. Green, formerly principal medical officer on the headquarters' staff of the Medical Research Council, has been appointed scientific secretary of the Trust with the chief responsibility for the executive organization of its spending policy.

\section{Message for the Foreign Ministers at Geneva}

ON October 21, on the eve of the meeting of Foreign Ministers at Geneva now in progress, a public meeting was held in the Central Hall, Westminster, to give expression to the sense of urgency widely felt that there should be a fruitful outcome of the discussions. The meeting was sponsored by Earl Russell, Lord Boyd Orr and Prof. C. F. Powell, and a message signed by them and Sir Richard Coppock was sent to Geneva. In it they refer to the Geneva meeting as the natural successor of the July meeting of heads of States, and continue : "At this moment, so crucial for the future of man, we should like to bring to the attention of the Foreign Ministers the warning signed by some of the most eminent seientific authorities in different parts of the world, which dealt with the perils of nuclear war. That statement suggested that neither the public nor the governments of the world are adequately aware of the dangers facing the human race. We feel that statement still to be true; and that the Foreign Ministers need to approach their discussions with a deeper awareness of these dangers. The Foreign Ministers, like all of us, have to learn to think in a new way. They have to ask themselves how they can reach specific agreements on the problems before them so that they will rule out any military contest of which the result must be disastrous to all.... We wish to impress on them the view that agreements on one problem will improve the possibility of agreement on others; but that disagreement on any one problem should not rule out discussion and negotiation of others. On the question of Germany and European security, it is good that the governments have recognized that these problems are closely linked. There can be no stable peace while Germany remains disunited, but its unification must be brought about in a way which will not involve an important accession of strength to either East or West and will help to end the division of Europe into two hostile blocs. On the question of a disarmament plan involving reduction of conventional arms, the abolition of nuclear weapons and an effective scheme of control, the viewpoints of both sides now seem so close that agreement ought to be possible". Other matters mentioned are further measures for the exchange of visits and information, the easing of trade restrictions as a contribution to world economic stability, and the recognition of the Peking Government. The message concludes : "In making the cold war a nightmare of the past, the Foreign Ministers 